\title{
OECDpublishing
}

\section{WOMEN'S ROLES IN THE WEST AFRICAN FOOD SYSTEM:}

\author{
IMPLICATIONS AND \\ PROSPECTS FOR FOOD \\ SECURITY AND RESILIENCE
}

\section{WEST AFRICAN PAPERS}

October 2016 No. 03 



\section{WOMEN'S ROLES IN THE WEST AFRICAN FOOD SYSTEM:}

\section{IMPLICATIONS AND PROSPECTS FOR} FOOD SECURITY AND RESILIENCE

This paper has been prepared by

DONATELLA GNISCI

Senior specialist in international development and human resources 


\section{WEST AFRICAN PAPERS}

The West African Papers series is designed to share studies with a wide audience of specialists, practitioners, decision-makers and the informed public. The series explores the nature, dynamics and characteristics of African social, economic and political transformations from a regional and multidisciplinary perspective. It seeks to stimulate discussion and gather information to better anticipate the changes that will shape future policies. Papers are available in English and/or French, and summaries are available in both languages. Initiated by the Sahel and West Africa Club (SWAC) to highlight and promote West African issues, the work presented is prepared by its Secretariat, Members and partners; other OECD departments; related international organisations; and associated experts.

For more information on the Sahel and West Africa Club: http://www.oecd.org/swac.

Please cite this publication as:

Gnisci, D. (2016), “Women's Roles in the West African Food System: Implications and Prospects for Food Security and Resilience", West African Papers, No. 03, OECD Publishing, Paris. http://dx.doi.org/10.1787/5jlpl4mh1hxn-en

Author contact: donata.gnisci@gmail.com

ISSN 2414-2026

OECD Working Papers should not be reported as representing the official views of the OECD or of its member countries. The opinions expressed and arguments employed are those of the authors.

This document and any map included herein are without prejudice to the status of or sovereignty over any territory, to the delimitation of international frontiers and boundaries and to the name of any territory, city or area.

Working Papers describe preliminary results or research in progress by the author(s) and are published to stimulate discussion on a broad range of issues on which the OECD works. Comments on Working Papers are welcomed, and may be sent to the Sahel and West Africa Club, OECD, 2 rue André-Pascal, 75775 Paris Cedex 16, France.

Authorised for publication by Laurent Bossard, Director, Sahel and West Africa Club Secretariat (SWAC/OECD).

(C) OECD 2016

You can copy, download or print OECD content for your own use, and you can include excerpts from OECD publications, databases and multimedia products in your own documents, presentations, blogs, websites and teaching materials, provided that suitable acknowledgment of OECD as source and copyright owner is given. All requests for commercial use and translation rights should be submitted to rights@oecd.org. 


\begin{abstract}
This paper examines how women's empowerment is essential for food and nutrition security and resilience in West Africa and suggests policy "pointers" arising from the West African experience that can help inform policies and strategies, particularly in view of the 2030 Agenda for Sustainable Development. West African women play a significant role at each stage in the food system, from production to distribution to nutrition, and they contribute to building resilience and adaptability to uncertainty and shocks including the effects of climate change. While it is clear that women significantly contribute to the eradication of hunger and malnutrition, it is also evident that there is a need for greater political representation and participation in policy dialogues.
\end{abstract}

Keywords: gender, women, food systems, empowerment, West Africa JEL classification: J16, R11, R58, Q18, Q01, Q15

\title{
RÉSUMÉ
}

Cette note montre en quoi l'autonomisation des femmes est essentielle à la sécurité et à la résilience alimentaire et nutritionnelle en Afrique de l'Ouest. Elle suggère des arguments éclairés tirés de l'expérience ouest-africaine pour nourrir les politiques et stratégies en vue de l'agenda international pour le développement durable à l'horizon 2030. Les femmes ouest-africaines jouent un rôle important à chaque étape du système alimentaire, de la production à la nutrition en passant par la distribution. Elles contribuent à renforcer la résilience et la capacité d'adaptation aux incertitudes et aux chocs tels que les effets du changement climatique. Alors qu'il est clair que les femmes aident de manière significative à l'élimination de la faim et de la malnutrition, il est également évident qu'elles doivent être mieux représentées politiquement et participer davantage au dialogue sur les politiques.

Mots clés : genre ; femmes ; systèmes alimentaires ; autonomisation ; Afrique de l'Ouest

Classification JEL: J16 ; R11 ; R58 ; Q18 ; Q01 ; Q15 


\title{
NOTE FROM THE SECRETARIAT
}

In early 2015, the Members and partners of the Sahel and West Africa Club (SWAC) asked the Secretariat to facilitate a process of experience-sharing on the interactions between women's empowerment, gender equality, food and nutrition security, and resilience in West Africa (Expo Milano, 26-30 October 2015). The focus on women informed broader discussions on what is influencing West Africa's development and food security prospects, and what innovative policies and approaches can strengthen the resilience of the most vulnerable populations in the region. It also led to the adoption of the Milan Declaration by the members of the Global Alliance for Resilience (AGIR) - Sahel and West Africa.

\section{ACKNOWLEDGEMENTS}

The author would like to thank the organisers, presenters and participants of the 2015 Sahel and West Africa Club Forum for their insights and contributions, particularly related to the session on "Women's Empowerment, Gender Equality and Resilience", chaired by Carla Montesi, Director of the European Commission's Directorate of West and Central Africa. She would also like to thank the guest bloggers and other contributors to the SWAC@Expo Milano website who engaged in discussions on the state and prospect of women's empowerment and gender equality in West Africa over several months, sharing their ideas and experiences and raising challenging questions.

\begin{abstract}
ABOUT THE AUTHOR
Donatella Gnisci is a senior specialist in international development and human resources with extensive field work experience in East and West Africa. She has conducted research, co-ordinated policy analysis and published on gender, migration, conflict, peace and security, land reform and regional integration issues. She has also designed and co-ordinated the implementation of human resources and organisational developmentrelated projects and processes in the areas of: job evaluation, organisational design, diversity and change management. Previous roles include: UNV Programme Officer at the UNDP Senegal Office, Policy Analyst at the Sahel and West Africa Club Secretariat of the OECD, and Human Resources Manager and OD Consultant at the International Institute for Environment and Development (IIED). Donatella Gnisci holds a BA in International Relations from "La Sapienza" University, Rome, Italy and postgraduate degrees from the School of Oriental and African Studies (SOAS) and King's College London (University of London, UK). Contact: donata.gnisci@gmail.com.
\end{abstract}




\section{TABLE OF CONTENTS}

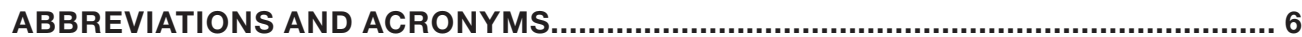

EXECUTIVE SUMMARY ...................................................................................... 7

1. FRAMING THE ANALYSIS AND THE REGIONAL CONTEXT ................................ 9

2. WHAT GENDER DATA SAY ABOUT WOMEN'S EMPOWERMENT

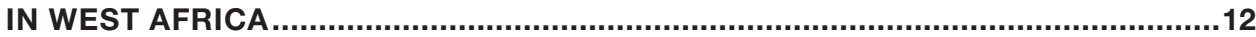

3. WOMEN IN THE REGIONAL FOOD SYSTEM ................................................13

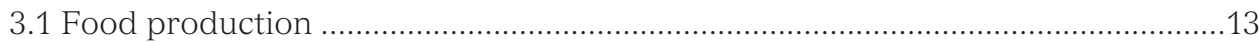

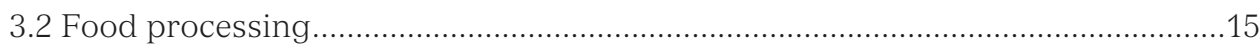

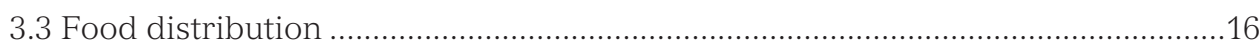

3.3.1. Greater integration into distribution networks ....................................... 17

3.3.2 Women's organisations and socioeconomic upgrading ............................17

3.4 CONSUMPTION AND NUTRITION .................................................................... 18

3.5 WOMEN, FOOD SYSTEMS AND THE ENVIRONMENT .......................................19

3.6 POLITICAL EMPOWERMENT AND REPRESENTATION CONCLUSIONS ............ 20

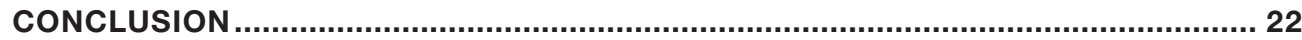

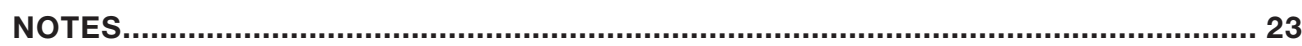

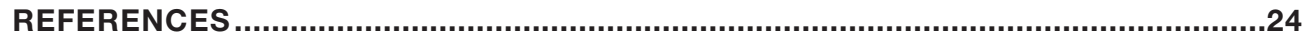

FIGURE

Figure 1. Gender equality indicators

\section{TABLE}

Table 1. Terminology and definitions used by the United Nations and the Global

Alliance for Resilience (AGIR) - Sahel and West Africa 


\section{ABBREVIATIONS AND ACRONYMS}

AfDB African Development Bank

AGIR Global Alliance for Resilience

CAADP Comprehensive Agriculture Development Programme

CILSS Permanent Inter-State Committee for Drought Control in the Sahel

CGIAR Consultative Group for International Agricultural Research

DAC Development Assistance Committee

ECOWAP ECOWAS' Agricultural Policy

ECOWAS Economic Community of West African States

ICMPD International Centre for Migration Policy Development

IFPRI International Food Policy Research Institute

IOM International Organization for Migration

FAO Food and Agriculture Organization of the United Nations

GII Gender Inequality Index

HDI Human Development Index

ILO International Labour Office

IPU Inter-Parliamentary Union

MDGs Millennium Development Goals

OECD Organisation for Economic Co-operation and Development

OECD/DEV OECD Development Centre

RPCA Food Crisis Prevention Network

SDGs Sustainable Development Goals

SIGI Social Institution and Gender Index

SWAC Sahel and West Africa Club

UEMOA West African Economic and Monetary Union

UNDP United Nations Development Programme

UNECA United Nations Economic Commission for Africa

UNEP United Nations Environment Programme

UNFCCC United Nations Framework Convention on Climate Change

UNFPA United Nations Populations Fund 


\section{EXECUTIVE SUMMARY}

E quality issues feature strongly in the new global development agenda that has emerged from the post-2015 process. ${ }^{1}$ Gender equality and women's empowerment are central to the analysis, policies and actions needed to address these issues. The 2030 Agenda for Sustainable Development recognises the interdependency between the building blocks of the better world in which humans aspire to live: people, planet, prosperity, peace, and partnerships. The 17 Sustainable Development Goals (SDGs) and 169 targets that form the core of the Agenda identify gender equality and the empowerment of women and girls as the focus of SDG 5 and as a crucial contribution to all of its goals and targets. ${ }^{2}$

On the African continent, the debate focuses on the need to recognise, better understand and promote women's roles in development and food and nutrition security as well as to strengthen women's contributions to the resilience of their communities. Women's political representation and inclusion in decision making are also priorities. In West Africa, emphasis is placed on economic empowerment and women's insertion in the formal economy, particularly vis-à-vis the rise of food value chains and structural transformation in rural and urban areas. Regional organisations such as the Economic Community of West African States (ECOWAS), the West African Economic and Monetary Union (UEMOA) and the Permanent Inter-State Committee for Drought Control in the Sahel (CILSS) are involved in strengthening the West African gender machineries ${ }^{3}$, and in promoting the participation of women's organisations in policy dialogue processes, for example for the adoption of regional agriculture investment plans and the review of the ECOWAS agricultural policy (ECOWAP+10).

This paper highlights examples of how women's empowerment is essential for food and nutrition security and resilience in West Africa, and vice versa. It discusses women's roles at each stage of the food system: production, processing, distribution, food consumption and nutrition; and it looks at their contributions to protecting the environment, formulating food-related policies and decision making. The participation of women in regional food systems is significant and raises new opportunities for empowerment due to the important demographic and socioeconomic transformations underway. Women's economic activities concentrate on high-value and high-potential food crops that respond to an ever-growing regional demand for prepared food. Realising this potential, however, is not without its challenges which include ensuring healthy and sustainable consumption, promoting effective use of productive resources that respect the environment, and increasing the productivity and competitiveness of local versus imported foodstuffs. Maximising women's roles in achieving food and nutrition security implies the take-up of policies and actions that help transform gender relations at household, societal and political levels.

Against this background, the following six points are proposed as ways to move forward on achieving West Africa's sustainable development objectives while not losing sight of the contribution that gender equality and women's empowerment can bring to the discussion:

1. Insist on policy coherence, co-ordination and implementation. This rests on three elements: 1) the full application of internationally-agreed gender policies and legislation at the local level; 2) greater gender sensitivity of all national policies and process via inclusive policy review processes; and 3) better knowledge and information-sharing to avoid the duplication of efforts, address gaps and play to different stakeholders' strengths in advancing the common agenda. The experience of AGIR - Sahel and West Africa is a case in point.

2. Embrace complexity. The complexity of sought objectives needs to be acknowledged and built into the solutions which are developed. Systems approaches to developmentrelated challenges are becoming more widespread as they are better able to analyse and harness the complex interlinkages between issues, sectors, actors, levels and timescales in the design of appropriate measures. 
3. Work simultaneously with the individual and the group. This is essential to build the critical mass of capacity and resources that would help to redress power imbalances and promote resilience. There would be value for the two communities of practice working on gender and resilience issues to share their experiences and learning, for example in the area of climate change adaptation.

4. Do not consider this as a woman's struggle only. The food and nutrition security agenda would gain from focusing more on gender issues, relations and equality and less exclusively on women's issues. Relevant advocacy networks that gather men and women together are worthy of support. Compelling evidence of how transformed gender relations are contributing to the achievement of food and nutrition security needs to be documented and more widely shared to promote change elsewhere. West African leadership at all levels is critical in setting the example.

5. Generate new data and use it wisely. Capitalise on the availability of disaggregated gender data and analysis at the international level and prioritise three regional objectives to develop West African food policies: 1) Increase the representation of women in all steps of data collection, analysis and dissemination; 2) Invest more in the dissemination of statistical information and analysis to improve availability, accessibility and usability by all stakeholders' and, 3) Make greater use of data to expose the diversity of existing situations and contexts and support the development of context-specific and tailored responses.

6. Dare to be innovative. Invest in the redesign of credit instruments, capacity building, financial and advisory services, legal and financial literacy training and other forms of support, especially to the most vulnerable and disadvantaged populations. Without new and innovative solutions and tools that are able to respond to different users' needs, long-standing, all-round capacity gaps and deficits will not go away. Capacity gaps and deficits hinder women from thriving in the regional food economy and beyond. Regional development actors and partners have the technical knowledge to develop suitable instruments and to create more opportunities for women's economic empowerment, however suitable funding and political momentum are key to bring about long-term and large-scale change and to obtain sizeable results. 


\section{FRAMING THE ANALYSIS AND THE REGIONAL CONTEXT}

W ow do the concepts of "change", "resilience", "women's empowerment" and "gender equality" interact to open pathways ${ }^{4}$ to food and nutrition security in West Africa? To start addressing the question, this paper will explore women's roles in West African food systems. ${ }^{5}$ Broad and evolving literature and related terminology exist for all of these concepts, however this paper applies the terminology and definitions agreed upon by the Food Crisis Prevention Network (RPCA) and the Global Alliance for Resilience (AGIR) Sahel and West Africa (Table 1) in their work.

West Africa is usually depicted as a region in change (von Grebmer et al., 2014; SWAC/ OECD, 2016; OECD/SWAC, 2013), where change refers to the demographic, socioeconomic and climate-related aspects of transformation. According to the State of World Population 2015, 367.2 million people live in 17 West African countries, ranging from 0.5 million in Cabo Verde to 182.2 million in Nigeria. ${ }^{6}$ Between 2010 and 2015, the regional average annual rate of population change accounted for $2.7 \%$. The proportion of population aged 10-24 years in 2015 was equal or slightly more than 30\% in all countries. The regional average dependency ratio (i.e. the ratio of people younger than 15 to the working-age population in the 15-64 year range) totalled 74.7\% (UNFPA, 2015). An ever increasing and younger population is a distinctive feature of West Africa: the total population is projected to almost double and approach 600 million by 2050 (OECD/SWAC, 2013). Steady urbanisation and long-established international, intra-regional and circular migration between rural and urban areas are important demographic trends (ICMPD, IOM and ECOWAS, 2015). From 1950 to 2010, the percentage of urban dwellers increased from $9 \%$ to $41 \%$ and this figure is projected to soar to $67 \%$ by 2050 (Moriconi-Ebrard, Harre and Heinrigs, 2016; OECD/SWAC, 2013). Urban growth concerns old and new towns, larger cities and smaller and rural centres alike (Ibidem). Settlement and mobility are deeply interlinked: $84 \%$ of migration flows in the region are directed toward another West African country. ${ }^{7}$

Rural areas are more densely populated and better connected to transport infrastructure, market facilities and urban consumers. They lie beneath the agricultural transformation underway which is marked by increased production and productivity, greater local processing and marketing of food products, and gradual economic diversification (OECD/ SWAC, 2013). Despite the global economic and financial crisis, West African countries have achieved high levels of economic growth in the last decade averaging 7\% in 2014 (AfDB, OECD and UNDP, 2014) before slowing down in 2015. According to the 2015 Human Development Report, in 2014 Cabo Verde and Ghana were the only West African countries classified as having "medium human development". Seven other West African countries figured among the bottom ten in the global list (Human Development Database accessed on 10 February 2015).

Poor and better-off households alike increasingly buy a greater variety of foodstuffs on the market and consume their meals in fast-food restaurants or from street vendors, thereby fuelling the demand for convenient, perishable and value-added products (Hollinger and Staatz, 2015). Food availability per person has increased, however, the access and quality dimensions of food security continue to represent considerable challenges. Progress in undernutrition rates are still uneven. In 2012-14, the proportion of undernourished people in the total population was below $10 \%$ in five countries only. Ghana showed the greatest decline from $43.7 \%$ in 1990-92 to 6\% in 2012-14. In the same period, undernourishment in Chad, Liberia and Sierra Leone concerned some 30\% of the population (FAO, 2015). Seven countries, in particular those affected by the Ebola crisis, saw the number of undernourished increase in 2015. 
Table 1: Terminology and definitions used by the United Nations and the Global Alliance for Resilience (AGIR) - Sahel and West Africa

\begin{tabular}{|c|c|}
\hline $\begin{array}{l}\text { Food security } \\
\text { (United Nations) }\end{array}$ & $\begin{array}{l}\text { When all people at all times have access to sufficient, } \\
\text { safe, nutritious food to maintain a healthy and active } \\
\text { life. It has four dimensions: availability, stability of } \\
\text { supply, access and utilisation. }\end{array}$ \\
\hline $\begin{array}{l}\text { Food and nutrition security } \\
\text { (UN Standing Committee on } \\
\text { Nutrition) }\end{array}$ & $\begin{array}{l}\text { When all people at all times have physical, social } \\
\text { and economic access to food, which is consumed in } \\
\text { sufficient quantity and quality to meet their dietary } \\
\text { needs and food preferences, and is supported by an } \\
\text { environment of adequate sanitation, health services } \\
\text { and care, allowing for a healthy and active life. }\end{array}$ \\
\hline $\begin{array}{l}\text { Food systems } \\
(\mathrm{FAO})\end{array}$ & $\begin{array}{l}\text { The resources, environment, people, institutions and } \\
\text { processes with which food is produced, processed, } \\
\text { stored, distributed, prepared and consumed. }\end{array}$ \\
\hline $\begin{array}{l}\text { Value chain } \\
\text { (FAO) }\end{array}$ & $\begin{array}{l}\text { Set of actors and activities that bring a basic agricul- } \\
\text { tural product from production in the field to final } \\
\text { consumption, where at each stage value is added to } \\
\text { the product. A value chain can be a vertical linking } \\
\text { or a network between various independent business } \\
\text { organisations and can involve processing, packaging, } \\
\text { storage, transport and distribution. }\end{array}$ \\
\hline $\begin{array}{l}\text { Gender equality } \\
\text { (United Nations) }\end{array}$ & $\begin{array}{l}\text { Equal participation of women and men in decision } \\
\text { making, equal ability to exercise their human rights, } \\
\text { equal access to and control of resources and the } \\
\text { benefits of development, and equal opportunities in } \\
\text { employment and in all other aspects of their liveli- } \\
\text { hoods. }\end{array}$ \\
\hline $\begin{array}{l}\text { Resilience } \\
\text { (AGIR) }\end{array}$ & $\begin{array}{l}\text { The capacity of vulnerable households, families, } \\
\text { communities and systems to face uncertainty and the } \\
\text { risk of shocks, to withstand and respond effectively to } \\
\text { shocks, as well as to recover and adapt in a sustainable } \\
\text { manner. }\end{array}$ \\
\hline $\begin{array}{l}\text { Women's empowerment } \\
\text { (UNFPA) }\end{array}$ & $\begin{array}{l}\text { Has five components: women's sense of self-worth; } \\
\text { women's right to have and to determine choices; their } \\
\text { right to have access to opportunities and resources; } \\
\text { their right to have the power to control their own lives, } \\
\text { both within and outside the home; and their ability } \\
\text { to influence the direction of social change to create a } \\
\text { more just social and economic order, nationally and } \\
\text { internationally. }\end{array}$ \\
\hline
\end{tabular}

Source: UN agencies and Global Alliance for Resilience (AGIR) 
Understanding change in West Africa raises three considerations. First, the different dimensions of change are heavily intertwined and their interplay can generate or obstruct the creation of development opportunities. Second, change dynamics are beneficial for some but problematic for others, depending on time, location and context. Above all, whether they represent an opportunity or an obstacle depends on actors' ability to take informed decisions, to freely determine courses of action and to build the resources required to maximise the benefits of change or tackle its negative consequences. Third, change puts pressure on the roles these very actors play (for example in the food system) forcing their mutual relationships to evolve. This situation is a catalyst for deeper societal and economic change per se and places issues related to capabilities, equality and equity centre-stage in the formulation of effective pathways to sustainable and inclusive development (Sen, 1999). These dynamics may seem to refer only to urban centres; however, high density rural areas experience similar change at an even faster pace (Moriconi-Ebrard, Harre and Heinrigs, 2016).

Dealing with change implies the notion of resilience, which has emerged as a key concept to understand how women and men, groups, systems and whole nations cope with, adapt and transform what they do and how they operate, in the face of change. Resilience embraces environmental, socioeconomic and political factors; it underlies the ability to react to adverse situations by addressing present negative circumstances without threatening future capacity to withstand new risks and shocks, thereby building actors' agency over time (OECD/DAC, 2014). Humanitarians, stabilisation and development practitioners and agencies work to build resilience from their own particular standpoint, but they all agree on a three-part approach to resilience, as the example of AGIR - Sahel and West Africa shows. First, the approach rests on concerted development interventions and investments that underline the complementarity between short-term actions, which address immediate needs, and long-term programmes that target structural causes and reinforce capacities. Second, this approach involves multi-stakeholder and multi-sectoral processes of dialogue and decision making. Third, it prioritises support to the most vulnerable people and encourages them to join supportive coalitions. This approach stems from a conviction that people's needs are most effectively met if they collectively mobilise to influence policy formulation and programming on issues that directly affect their lives (AGIR, 2013).

The resilience and empowerment agendas share the view that the most vulnerable are key agents of change in the development process (Forsythe et al., 2015; UNDP, 2014) and poor women are among the most food-insecure, vulnerable and disadvantaged people across geographical and socioeconomic contexts, West Africa included.

Empowerment is defined by different characteristics which share at their core the idea of "power". Oxaal and Baden (1997) highlight a well-established distinction in the literature between three diverse aspects of empowerment: "power to" refers to the authority to make decisions; "power with" relates to people uniting and organising to achieve a collective goal; and "power within" evokes self-confidence, self-awareness and assertiveness. These aspects suggest three levels where power is concentrated and where women's empowerment is crucial: household, community, and systemic/institutional. According to the Expert Group Meeting that prepared the 60th UN Commission on the Status of Women (New York, 14-24 March 2016), empowerment implies a broader spectrum of conditions, all of which are relevant to the West African context:

Women's empowerment goes beyond the idea that women are empowered when their capabilities are enhanced or when they are able to compete with men for jobs. Empowerment implies secure livelihoods, the ability to enjoy their human rights, a reduction in the unpaid work that hinders the enjoyment of rights, and meaningful participation as actors and leaders in their communities.'

\section{(UN Expert Group Meeting, 2016:1)}


Given the important role of women in care, food and nutrition security, production, employment and wider sectors of the economy, interventions and investments to strengthen women's empowerment can successfully bring many advantages to society (AfDB, 2015; Doucoure, 2015; Duflo, 2011; Teigner and Cuberes, 2015; and World Bank, 2012).

This view, however, does not go unchallenged (Esquivel, 2016; Leach, 2015; Lele, 1986; Sen, 2001, 1995; Tacoli et al., 2014; UNDP, 2013; and UN Women, 2014). For example, in her analysis of the SDGs, Esquivel argues that the 2030 Agenda for Sustainable Development does not have enough teeth to seize the transformative potential of the empowerment and equality issues it raises, because it does not fundamentally challenge the nature of the prevailing economic system and development model. Others stress that empowerment is potentially divisive in society because it defies existing power structures and forces the evolution of dominant social relations (Leach, 2015; Sen, 1995, 2001; Tacoli et al. 2014; UNDP, 2013; and UN Women, 2014).

Pursuing gender equality, therefore has multiple dimensions. Redressing socio-economic disadvantage in the world of work, well-being and access to resources appears to be the first priority (Leach ed., 2015:7), followed by enhancing recognition, dignity and respect for women's bodily integrity, sexual and reproductive health and rights, and specific forms of knowledge. Third comes promoting equal participation in decision making at all levels and supporting women's agency, power and voice in socioeconomic institutions and key policy processes or fora. The "Women's Empowerment, Gender Equality and Resilience" panel's conclusions at the Sahel and West Africa Forum (SWAC/OECD, 2016) echo Leach's argument. To reinforce this last point, the UN Expert Group Meeting suggests a new definition by which sustainable development "means economic, social and environmental development that ensures human well-being and dignity, ecological integrity, gender equality and social justice, now and in the future" (EGM, 2016:1).

\section{WHAT GENDER DATA SAY ABOUT WOMEN'S EMPOWERMENT IN WEST AFRICA}

ow levels of human development generally coincide with higher gender inequalities.

L The Human Development Report 2015 shows worsening values of its index for 10 of the 17 West African countries taken into account. Examining information on West African countries from three other gender-related indicators confirms this picture (Figure 1).

These different measures of women's empowerment and gender equality are a positive evolution per se compared to the early 2000s, and demonstrate a rising interest in these issues, globally. However, accurate, reliable and sufficiently disaggregated data are still fragmentary in West African countries.

Gathering information on the share and characteristics of female labour, namely within the food system, remains challenging. Based on ILO estimates for 2013, the regional median value of the percentage of the female population aged between 15 and 64 (labour participation rate) was $67.2 \%$, ranging from 29.4\% in Mauritania to $82.2 \%$ in Togo. The proportion of women in wage employment in the non-agricultural sector was higher than 30\% in Cabo Verde, Ghana, Mali, Mauritania and Niger in the early 2010s (UNECA, 2014). The FAO (2011a), on the other hand, observes that women represent almost 50\% of the agricultural labour force on the African continent (from about 45\% in 1980) with wide differences between countries. For IFAD (2015), women's share of agricultural employment in Sahelian countries accounts for 89\%.

The reliability and accuracy of these data have been questioned as the employment of women in the labour market is often underestimated (FAO, 2011a). Depending on the way surveys are tailored, they may fail to capture real female engagement in agriculture, 
ignoring agricultural production for household consumption or activities such as rearing small livestock, kitchen gardening, and post-harvest processing; or they may give priority to the role of women as primary caregivers over their contribution to family or community farming. Moreover, while male and female labour contributions to food production tend to be distinctive and context-specific, they are not always separated and it is difficult to quantify food outputs by sex. Further research is required, for instance, to better grasp differences in gender roles in producing and processing high-value food products in rural versus urban areas, and on the impact of urban-rural linkages on transforming gender roles in the food economy, creating new opportunities for women's socioeconomic empowerment.

\section{WOMEN IN THE REGIONAL FOOD SYSTEM}

A cross cultures, gender is a key factor that shapes the division of power, labour and resources between women and men. Gender roles and the segmentation of economic activities between men and women appear to be fluid and flexible in a context where changes in demography, society, markets and technology are large-scale, rapid and simultaneous (Lele, 1986). ${ }^{8}$ This statement holds true for contemporary West Africa, and three factors are shaping the current situation in the region. Agriculture plays a less sizeable role within the regional food economy than in the past; $40 \%$ of the value added in the agro-food sector is no longer dependant on agriculture. Increasing urbanisation and human mobility are influencing the evolution of food diets, social habits and the profile of agricultural labour, including in rural areas; and the post-harvest segments of the food value chains are expanding in line with socioeconomic change (Allen and Heinrigs, 2016).

The overview that follows of women's roles and activities at each step of the food system (i.e. production, processing, distribution, consumption and nutrition, environmental protection, and participation in shaping the food economy's policy framework) is to be read with this observation in mind. An analysis of how men's roles are evolving would be an equally critical and timely effort and would paint a comprehensive picture of how resilience and food and nutrition security can best be achieved.

\subsection{Food production}

West Africa's women are economically active food producers. They are involved in producing staple food crops that are among the top ten crops grown in the region (in acreage): millet, sorghum, cow peas, maize, groundnuts, cassava, rice and yams (World Farmers' Organisation website accessed on 26 February 2016). The horticulture sector mainly employs female labour as well. Cereals, roots and tubers, fruits and vegetables are essential for food and nutrition security and have a growing regional market. Yet low productivity and competitiveness, segmented transport infrastructure and other market barriers makes it more convenient to buy imported products. Female farmers who produce to sell on the market regularly experience these obstacles more severely than their male counterparts - a situation which undermines their capacity to grow their businesses, when it does not directly threaten their human security (IFAD, 2015; OECD/SWAC 2016).

The cotton-cereal and crop-livestock systems in the Sahel show that the production of staple food, cash crops and livestock is complementary and intertwined (OECD/SWAC, 2006; Kaminsky, 2008; FAO document repository accessed on 2 March 2016). Women and men work side-by-side albeit with distinctive cropping patterns: they often cultivate separate crops or tend to different livestock. They can also cultivate the same crops on separate fields for local consumption and the market. Task allocation tends to be genderspecific; however, most food is produced with the labour contributions of women and men working together. Gender roles are distinct but closely related and increasingly flexible, as observed in the case of women-managed farms and for some cash crops (e.g. shea butter). Different "centres of decision" are associated with different crops and fields and mobilise different intra-household groups involving both men and women, either 
Figure 1

Gender equality indicators

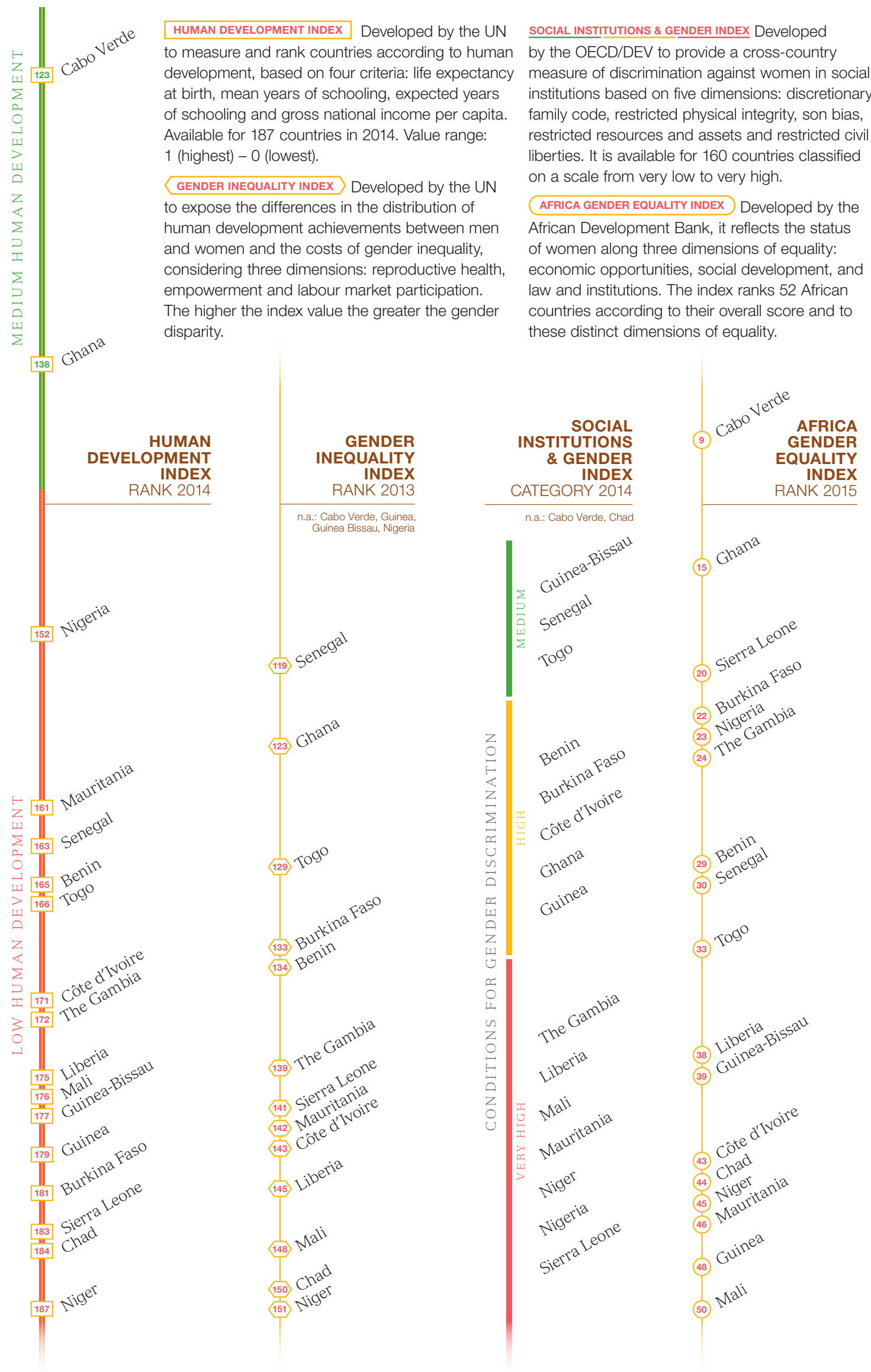

Source: Adapted from Human Development Index, Gender Inequality Index, Social Institutions and Gender Index, Africa Gender Equality Index 
together or independently (Gafsi et al., 2007; FAO, 2011b). This impacts what crops they should grow and when they should harvest, how they should earn or spend their income, what food they should eat and how they should raise their children. The study by Duflo and Udry (2004) on intra-household resource allocation in Côte d'Ivoire, illustrates this point. Households involved in cocoa production do not work as a sole unit: the use and distribution of income from agricultural production is the outcome of negotiations between members who have distinct but interrelated sources of earnings and different priorities and goals. Economic diversification beyond agriculture concerns even the poorest households to reduce vulnerability to sudden economic or other shocks.

Working together to produce food and other agricultural products, women and men also share access to land, inputs and other productive resources, advisory services, technology and infrastructure. This reality, however, conceals deep-seated inequalities in the collaboration between men and women in agriculture. Female producers have access to less productive resources, inputs, credit, training and support compared to male farmers. Insecure land tenure means that women are less able to manage land use effectively and that they have fewer incentives to invest in land improvements. When they do, legal obstacles, bank practices and cultural assumptions limit their access to appropriate financial services. Similar barriers and higher levels of illiteracy hinder women's ability to benefit from information and training on the same footing as men.

Women's labour contribution is significant, with the cautions on data expressed in the previous section. The feminisation of agriculture is linked to greater male rural-urban mobility, structural change, conflict and the consequences of HIV/AIDS (Leach, 2015). However, women still hold the majority of part-time, vulnerable and informal employment in these countries. They either contribute to the least skill-intensive segments of food value chains or are paid less than men for similar work. They carry out a considerably higher amount of care work and unrecorded household tasks at the same time as they produce food. These tasks tend to be heavy, time-consuming, unpaid and undervalued (e.g. fetching water and fuelwood); hence their more equal allocation meets resistance within the household and the community.

These constraints reduce women's productivity in agricultural production: in 2014 in Niger, the gender productivity gap was equal to 19\% (World Bank, 2014), with negative consequences for food security. Several studies emphasise the social costs of women's lack of education and assets, particularly in rural areas and marginalised urban settlements, establishing a direct link with high rates of undernutrition and infant mortality. Low agricultural productivity also bears economic costs at the national level, for example, the gender gap could cost Niger's economy over 23\% of its GDP (AfDB, 2015).

Closing the gender employment, productivity and pay gaps implies going beyond access issues (World Bank, 2014) and tackling entrenched power imbalances within and outside the household. Representatives of women's organisations at the Sahel and West Africa Forum evoked the following priorities to meet this goal. First, enhance women's legal and economic rights to control productive resources and to build and diversify their sources of income; second, provide more adapted financial instruments and advisory and support services which better suit women's needs, work schedules and learning preferences; and third, make access to technology and innovations and greater participation in decision making more inclusive at the household, local and policy level (SWAC/OECD, 2016).

\subsection{Food processing}

Three broad categories of processing activities are typically associated with female employment in West Africa (ECOWAS and SWAC/OECD, 2008; FAO document repository accessed on 2 March 2016). The first category relates to primary and secondary processing of grains, nuts, roots, tubers, fruits and vegetables. It involves cleaning, grinding, hulling, pounding, milling, tempering, soaking, parboiling, drying, and sieving on the one hand; and baking, frying, cooking, extruding, blending, fermenting and roasting, on the other. 
The second category is linked to farming and processing poultry and small livestock and entails the preparation, cooking, packaging and marketing of eggs, poultry and meat pieces, local milk and dairy products. The third category concerns the handling and processing of fish on-shore and involves salting, fermenting, sun-drying and smoking fish or pounding fish and seafood into a fine powder for cooking purposes.

These post-harvest activities typically attract both female labour and entrepreneurship. The African Development Bank (AfDB) (2015) notes that the large number of women in businesses related to food production and processing are common in Africa, and specifically in West Africa, where women are often highly entrepreneurial, but also because they lack other alternative employment options. African female entrepreneurs are members of a diversity of associations or coalitions that help them overcome the barriers to acquire the equipment, inputs, resources, know-how, information and contacts necessary to set up viable businesses.

Female employment and entrepreneurship prevail in many of the potentially high-value food chains in West Africa, for which programme evaluations document a number of success stories. In Casamance, Senegal, for instance, fish processing is a high-potential sector controlled at $90 \%$ by women in which hired labour is mainly male. Combined interventions to modernise equipment, build the technical, productive and managerial capacities of these entrepreneurs, and improve sanitation, hygiene and safety standards are contributing to strengthening the resilience of women in fish processing, increasing their social and economic empowerment, and promoting more environmentally-friendly products (EmpowerWomen website accessed on 10 August 2015). In Senegal and Ghana, greater access to appropriate business training, financial and advisory services, supports the emergence of rural businesswomen who combine activities as producers and entrepreneurs to increase their incomes (AfDB, 2015; IFAD, 2015). Similarly, the Fédération nationale des industries de l'agro-alimentaire et transformation (FIAB) in Burkina Faso attempts to maximise the participation of female entrepreneurs in strategic food value chains (SWAC/OECD, 2016). Improving access to capital and technology, strengthening technical capacities and managerial skills are essential to maintain and even expand women's share in food processing. Food value chains in West African countries are increasingly attracting new, highly competitive actors, including from abroad, who are better equipped to meet safety and quality standards. Many food processors in the informal economy risk losing their dominant position, unless their businesses becomes more resilient to shocks and better structured to seize opportunities for growth.

\subsection{Food distribution}

In 2002, in the Ivorian town of Odienné, women managed 72\% of the town's selling points and $80 \%$ of food vendors and restaurateurs were female (OECD/SWAC, 2002). Two-thirds of these activities were informal. This reality holds true today, but another factor has been emerging since the early 2000s which alters the picture of food distribution.

Market women continue to be the pivot of the local food distribution system and have a monopoly on street-food vending (Otoo et al., 2009). Preparing and selling food remains the second source of income for women after agricultural production. Women often combine food production, processing and distribution in the same business to increase and diversify their sources of income. Not only does this activity provide them with employment and earnings from which their dependents benefit as well, but it also supplies the urban poor with inexpensive and nutritious food. African women are still more likely to be self-employed in the informal sector than to be formal employees earning a regular wage (AfDB, 2015). However, Otoo et al. (2009) documents several cases in Côte d'Ivoire, Ghana, Nigeria and Senegal where female entrepreneurs have managed to totally or partially exit their agri-food business from informality.

A new feature is shaping the landscape of West African cities and towns, including those in poorer and rural areas. Supermarkets are mushrooming to attract customers from 
increasingly densified areas and a rising middle class estimated at circa 70 million (ACET, 2013; Hollinger and Staatz, 2015; SWAC/OECD,2016). These new retailing activities arise from the expansion of South African supermarket chains to the rest of the continent, and particularly in East and West Africa (Dakora, 2012). The rise of supermarkets has multiple consequences on West Africa's retailing: it is a significant opportunity for producers, processors and intermediaries who have seen the demand for fresh, local products grow exponentially. However, seizing this opportunity is problematic due to the strict procurement conditions supermarkets implement, i.e. compliance with thorough quality and safety standards, capacity to offer competitive prices, and to ensure a reliable and stable supply. Women farmers and entrepreneurs are at disadvantage in establishing business partnerships with big retailers. Their less secure access to productive resources and credit instruments undermines their capacity to provide a regular supply of food products of the required quantity and quality. Poorer technical and managerial skills and an information deficit also disproportionally affect the ability of women-led businesses to comply with supermarkets' procurement systems. In addition, supermarkets are mighty competitors for female street vendors because they also target a similar market segment composed of people who have little time to prepare a meal from unprocessed ingredients and who consume food away from the home. The increased demand for processed food, and the underlying socioeconomic change, can only continue in future decades. The next section looks at factors worth considering for female entrepreneurs to seize the opportunities for economic empowerment arising from this change.

\subsubsection{Greater integration into distribution networks}

If women were more solidly integrated into the distribution networks at the heart of regional food value chains, they would be better able to gain influence, but this is still far from being the reality. It takes time and capacity to build the necessary social capital and trusted relationships. Appropriate financial resources are required to join these networks, and to collaborate and compete in an already crowded arena. For example, female greengrocers in Cabo Verde need to know where to obtain the best supply for their businesses, be it from the countryside or from urban wholesalers. Based on this knowledge, they need the capacity to freely move around and meet their suppliers wherever they are based, and the financial resources to transport these goods to market, where they pay fees regardless if their stalls are located within a market or in its margins.

The AfDB (2015) observes that the absence of opportunities and alternatives drives women into small businesses that are engaged in low value added activities which only secure marginal returns. Microentreprises are a key source of income for many poor households and they can help absorb the negative effects of shocks and stresses in the short-term. However, they cannot eliminate vulnerability or allow these economic actors to further integrate into networks and markets. Investing in women's financial and human capital would translate into greater confidence, awareness, and risk management capacity, all abilities that are critical to coping with situations in which they encounter resistance, obstruction and, at times, violence which is the case, for example, of women who mobilise the trade of food products across the region.

Testimonials by Senegalese food entrepreneurs show how the struggle for women's economic empowerment is not only a women's struggle, but a societal one as well (Gnisci, 23 June 2015). It requires the promotion of solidarity and collaboration between men and women in order to address power imbalances that limit women's voice and agency within households, in national and transitional trade networks and in relevant policy circles.

\subsubsection{Women's organisations and socioeconomic upgrading}

The number of women's professional organisations, societies and associations in West Africa are countless at the community and national level and they are increasingly visible at the regional level. These organisations provide an effective instrument for co-operation and solidarity that increases the capacity of their members to penetrate regional distribution networks. They ease access to financial resources, equipment, knowledge and advice for 
starting and building a business. They assist with connecting all actors upstream and downstream in the value chain (i.e. representatives of the private sector and civil society organisations with public authorities and agencies, advisory services, financial institutions, development partners, consumers, etc.) so that they can negotiate on matters of common interest. Women's organisations also have a role in sharing knowledge, information and contacts, thereby building organisational and individual capacity. However, not all organisations are able to reach the most marginalised of their potential members and a problem of representation, or lack of it, can arise.

\subsection{Consumption and nutrition}

In West African societies, women and girls provide the bulk of reproductive labour, i.e. unpaid and volunteer labour for care, subsistence and reproduction (Leach, 2015, p. 9) of the community. Preparing food for their dependents and extended families has a central place among these duties and raises three interrelated points.

First, women's roles in nutrition are central in both the private and public spheres. Women are proportionally more present than men in food utilisation, an essential dimension of food security with a direct link to consumption and nutrition. They are essential to delivering an affordable, accessible and diversified diet without generating nutritional and environmental harm in the way it is prepared, both at home and in the food catering sector. As grandmothers, mothers, wives, sisters and daughters, women produce or acquire the food ingredients which they will store and use to prepare meals. As food vendors, they provide a similar service to their customers. The diversity of the diet is a function not only of women's purchasing power but also of their knowledge and abilities. Whether the food they provide is healthy and nutritious depends a great deal on food practices and preferences in relation to: cooking time, taste, ease of collection, preparation, preservation, and waste disposal. In this respect, the case of Ghana shows that rapid decline in household income poverty and caloric undernourishment can be insufficient to address malnutrition (Leach, 2015: 89). Enduring malnutrition is generally linked to either ineffective utilisation of food due to poor health and environmental conditions (e.g. absence of clean water and sanitation), or to the unequal distribution of power within the household.

Second, the responsibility for intra-household distribution of food generally falls on women's shoulders, but gender dynamics, age and status will determine women's effective power or influence over food-related decisions, task allocation when dealing with food preparation and access to nutritious food for themselves and for their children. Those who prepare and serve a meal are often the last to eat (SWAC/OECD, 2016). Girls and young women are the most at risk of nutrition and health problems. They have heavy workloads (e.g. planting, weeding, harvesting and threshing crops, processing produce for sale at the same time as they carry out household tasks like water and wood collection) and their bodies can be weakened by early or serial pregnancies and by the efforts of breastfeeding and child-rearing. In poorer households, they cannot secure stable access to adequate and nutritious food because they have less control over it. In most West African countries there still are severe limitations on young women's access to public health services, as reported by UNECA (2014) on progress made in achieving MDGs 3 (promote gender equality and empower women) and 5 (improve maternal health).

Third, it is difficult to neatly separate the time women allocate to food and nutrition from other uses of time. Alongside carrying out responsibilities for care, women are progressively more involved in the cash economy (UNDP, 2014, 2013) vis-à-vis the production, processing and distribution of foodstuffs. Conflicting demands on their time trap those responsible for care in a chain of circumstances which prevents them from contributing to better nutrition and improved food security (including theirs), and from achieving social and economic advancement through their contributions to the food economy.

This picture partly accounts for why West Africa still holds high malnutrition rates despite notable improvements. The region-wide prevalence of undernourishment has 
shrunk by $60 \%$ since 1990 , decreasing from $24.2 \%$ to $9.6 \%$ even in the face of adverse circumstances (shocks related to environmental degradation and climate change, violent conflict and insecurity, disease outbreaks, etc.) (FAO, IFAD and WFP, 2015). This result is driven by progress in countries like Ghana and Nigeria and is by and large linked to greater availability of staple foods through a combination of increased regional production and cheaper imports. Greater consumption of staple foods, however, has not addressed dietary imbalances and explains why the prevalence of underweight children has not fallen as rapidly, i.e. from $26.1 \%$ to $20.5 \%$ in two decades. Moreover, the prevalence of anaemia in reproductive women is higher than in the rest of the continent, except for Mauritania. In other West African countries, anaemia affects more than $40 \%$ of women ("very high prevalence category" - FAO, 2015). Improving access to health care services and information for women, including sexual and reproductive health services and rights, is as crucial for women's empowerment as for food and nutrition security (Sandars, 2015).

Two considerations emerge from this: social and economic empowerment, underpinned by greater control of one's own time and higher human development, is a priority for West African women. The challenges to food consumption and nutrition transcend the household, the role of women, and the exclusive focus on production. A policy focus is needed that cuts across sectors: education, health, infrastructure, water, sanitation, trade, agriculture, macroeconomic policies, market frameworks, social protection, etc.

\subsection{Women, Food Systems and the Environment}

"Women in development", "gender in development" and "gender mainstreaming" (United Nations Office of the Special Adviser on Gender Issues, 2002) ${ }^{9}$ are theoretical approaches to women's issues in the development process that have informed the rational for relevant policies and interventions but have often failed to grasp the complex and fluid nature of these roles and their intersection with other dimensions such as age, class, culture, ethnicity, status, etc. The debate on gender and the environment is a case in point, where all too often women have been described as either victims or "sustainability saviours" (Leach, 2015; Meinzen-Dick, Kovarik and Quisumbing, 2014). Women can provide distinctive contributions to environmental conservation, the sustainable use of natural resources, and climate change adaptation. However, other conditions need to be in place in order to maximise these roles and build resilience, including greater political empowerment and redressing of power imbalances.

In the Sahel, climate change and climate variability exacerbate the occurrence of extreme weather events such as droughts and seasonality which disrupt food production cycles. This disruption is suffered by all populations, but the poor and particularly women, are most vulnerable to their negative effects. The marginal lands they tend to cultivate are likely to be worse hit by desertification and soil erosion. Collecting water and wood takes more time and requires walking longer distances, often in adverse or unsafe conditions. Women's health and nutrition are jeopardised in this setting, with negative implications for their young children and other dependents.

Facing the same circumstances and constraints, men and women have developed diverse expertise and adaptive strategies due to gender differences in labour, land rights, resource access, decision-making power and perceptions - all factors that shape their knowledge systems. Research and programme evaluations carried out by UNEP, FAO and IFAD (2012) underscore how the effects of climate change, environmental crises and disasters push women producers to experiment with different combined experiences and innovations. These relate to soil and crop characteristics, the use of natural vs. chemical fertilisers, timings of ecosystems, etc., so as to protect the soil, water and natural vegetation. They also experiment with activity diversification in order to secure their income. In the lake Faguibine area of Northern Mali, for example, reduced water levels mean that traditionally dominant water-dependent activities are less relevant for women's livelihoods. For this reason, they are moving into new economic activities based on forest resources in the former lake area, like charcoal production (Djoudi and Brockhaus, 2011). 
Beyond consumption, women use wild plants and bush products to make juices, medicines, paint etc., that become an important source of income to buy more food or other basic necessities on the market. In the Sahel alone, more than 800 species of edible wild plants have been catalogued to date, (UNEP, n.d.). According to the FAO, forest plants and animals are equally important for the food security of West African rural populations, in terms of availability (emergency, seasonality and year-round), nutritional value and culture (taste, tradition). West African indigenous communities, for example in Côte d'Ivoire, Guinea, Liberia and Sierra Leone, understand how to manage biodiversity for consumption and income generation in ways that do not undermine the environment and its use by future generations, as documented by Fraser, Frausin and Jarvis (2015).

Motives, means and opportunities to contribute to biodiversity conservation and sustainable use are shaped by gender roles. UN agencies advocate for making the differences in practices and knowledge between women and men more visible to show that these contributions are different but equally valuable for biodiversity. The Convention on Biological Diversity Secretariat acknowledges four ways in which indigenous knowledge of biodiversity and local food systems differs between men and women: men and women know about completely different things; they have different knowledge of the same things; the way they organise their knowledge is different; or they receive or transmit knowledge through different means (CBD Secretariat, 2004).

Though men and women may share equally important knowledge of biodiversity, their access to power remains unequal and this is proven to affect conservation outcomes (Elwell and Williams, 2016). Still women tend to experience less access to and control of biodiversity resources due to their limited participation in decision making and in social and political institutions that regulate conservation, both locally and nationally.

\subsection{Political empowerment and representation}

For empowerment to be transformative it must be seen as a process existing on [...] individual, group and societal [levels]. Unless the gendered power structures that subordinate women on the societal level are addressed, individual women cannot take full control over their lives. And unless a group of women feel worthy of safety and (are) able to act together, a law prohibiting violence against women will have little effect [...].

The different levels are interconnected and mutually reinforcing [...]. While a new law that grants equal inheritance rights is the result of the empowerment of the women who brought about the law and not women in general, it encourages the empowerment of the latter (if they are aware of the law). Gender equality is hence both an outcome of the empowerment of the women who brought about the changes, and an encouraging factor for women's empowerment on the individual level. But where gender equality describes a state, empowerment describes a process." Professor Naila Kabeer (2012: 6-7)

During the last two decades the world's percentage of women in parliament has almost doubled; nonetheless, women still make up only $22 \%$ of parliaments, according to the UN “Planet 50-50 by 2030: Step it up for Gender Equality" campaign. With 42.7\% of parliamentary seats assigned to female elected officials as of June 2015, Senegal ranked sixth out of 191 countries on the Women in Parliaments list; Rwanda holds the world's top place with 63.8\% while the average for sub-Saharan Africa is 23\%. Besides Senegal, only Mauritania (25\%) has a higher female participation rate than the African and global averages. Guinea is next with 21.9\%; Liberia twice-elected the first African woman head of state, but the proportion of women's seats in parliament remains just above $10 \%$.

However, limited political representation (i.e. less than 12.5\%) in, for example, Côte d'Ivoire, Ghana and Nigeria seems at odds with the economic power women can enjoy in those 
countries, especially in trade and agriculture (IPU website accessed on 10 August 2015). In Côte d'Ivoire, for example, the share of firms with female representation in ownership is above $60 \%$ (AfDB, 2015).

The African Union promotes gender parity in its top decision-making positions in the Commission, the Pan-African Parliament and other institutions, and gender equality is a cornerstone of the Agenda 2063, the new pan-African vision and strategy for the next fifty years. ECOWAS, UEMOA and the AfDB all have a dedicated department, centre, special envoy or strategy on gender. Together with the Beijing Platform for Action +20 , these instruments provide the policy framework, priority areas and review mechanisms that inform gender-related national policies and strategies. By 2014, seven countries had adopted such a policy or strategy: Cabo Verde, Côte d'Ivoire, Ghana, Nigeria, Senegal, Sierra Leone and Togo (UN Women, 2014). Moreover, all West African countries have signed the Additional Protocol (Maputo Protocol) on Women's rights to the African Charter on Human and People's Rights, though Chad, Niger and Sierra Leone have not yet ratified it. All countries have ratified the Convention on the Elimination of All Forms of Discrimination against Women (CEDAW), albeit with reservations from Niger.

Regional and national sectoral policies and legislation with a gender dimension are on the rise in the areas of inheritance and property rights, marriage and divorce, HIV/AIDS, violence against women, natural resource management and fiscal reforms (Kuwonu, 2015; SIGI database accessed on 10 August 2015; and UN Women, 2014). The African Development Bank (2015) acknowledges the role of these policies to help establish a new generation of African women leaders in institutions, businesses, civil society groups, associations and universities, who are involved in policy negotiations, economic activities and peace processes.

Against this positive outlook, greater political representation of women in policy and decision making faces difficult constraints to overcome in the short-term. To begin with, many women living in poor, disadvantaged or remote areas remain unaware of their enhanced rights in new land, family and property laws. Acquiring knowledge of these rights is fundamental for women to gain greater confidence, awareness and ultimately assertiveness - the building blocks of greater voice and agency in the political process. Women in Law and Development in Africa (WiLDAF), an organisation which supports legal literacy and awareness of relevant legal tools (SWAC/OECD, 2016), finds that interventions are most effective when whole communities (i.e. single individuals, organised and representative groups, local authorities and other influential figures) are involved rather than women only. The more local leadership becomes sensitive to gender equality legal obligations, the more it supports greater inclusion of women within decision-making systems (Kuwonu, 2015).

The limits of women's political participation at national level are evident, for example, in current West African agricultural investment plans (Kuwonu, 2015). Not only are genderrelated issues hardly included in the situation analysis that informs these plans, but they also rarely figure among the key actions identified, let alone the funding and monitoring mechanisms that have been developed. With the exception of few countries (e.g. Burkina Faso), women's organisations are absent from the consultation process. At the same time, enabling more women to participate in the formulation of plans is not sufficient enough to guarantee that diverse issues and perspectives for agricultural development will be raised in the final documents. The quality and completeness of these plans highly depends on individual and organisational capacity to effectively negotiate, and for all stakeholders to possess greater sensitivity to gender issues. 
Across the region, women's political empowerment and representation is undermined by the fact that eleven West African countries still feature on the 2015 OECD list of 50 fragile countries and economies (OECD, 2015). A vast literature emphasises that women and girls tend to suffer disproportionately in armed conflicts and protracted crises, and UN Security Council Resolution 1325 acknowledged in 2000 that wars impact women and men in different ways.

The examples from Côte d'Ivoire, Liberia and Sierra Leone also demonstrate how, in a situation emerging from conflict where violence has been pervasive and long-term, successful political and economic reforms, institution-building and the rule of law take time, continuous investment and an integrated approach to address multiple priorities and to focus on their interlinkages. A post-crisis situation raises expectations and provides opportunities to deal with complex and entrenched problems, including power imbalances and inequalities which seemed untouchable before (Chauveau and Richards, 2008).

\section{CONCLUSION}

$\mathrm{T}$ his paper has presented women's roles in West African food systems, emphasised their relevance to eradicate hunger and malnutrition, and highlighted their evolving character. The interwoven consequences and dynamics of demographic, socioeconomic and climate change observed at the local level interact with national, regional and international processes of political and economic transformation, to modify these roles. A case in point: urbanisation and the rise of food value chains have propelled traditionally female activities at the heart of the regional food economy, i.e. the production, processing and distribution of staple food crops, horticultural products, small livestock, fishery and dairy products. Besides, implementing the MDGs has magnified vulnerability and sustainability issues on the global political agenda and highlighted the importance of local knowledge and the adaptive capacity of different stakeholders. This has also acknowledged, in unprecedented ways, women's contributions to diversifying livelihoods and withstanding the effects of climate change and protracted crises on food and nutrition security. The post-2015 process shows the universal character of the challenges related to better nutrition and sustainable consumption and has spurred interest in the care economy for which women are primarily responsible (UNDP, 2013). Finally, the 2030 Agenda for Sustainable Development has made women's empowerment and gender equality an essential condition for its achievement. Projects, initiatives and funding targeting women have mushroomed; interest in and momentum for gender issues seem to be at their highest.

Yet many women and girls in West Africa have been unable to transform their lives, despite noticeable improvements in their social, economic and political needs and aspirations (UNECA, 2014). Low human development; inadequate skills and capacities; unequal access to resources, opportunities, knowledge and support; and continuing marginalisation or discrimination in collective decision making at different levels, are still widespread. The threat of violence and the lack of control of one's own time and efforts are also significantly limiting factors.

West African women's organisations are potent allies of female entrepreneurs and workers in the food sector helping them to ease their insertion in food value chains and increase their participation in food and agriculture-related policy dialogue. The missions of these organisations span technical support and advice, service delivery, credit facilitation, capacity building, legal literacy, policy advocacy, representation and more. A constellation of local and national organisations is influencing policy and programming within the ECOWAS-UEMOA-CILSS framework and the African Union, complementing their role as implementation agencies of region-wide projects that support women's economic empowerment and resilience. 
West African countries, regional organisations, the African Union and development partners are prioritising resilience which they see as an entry point for achieving food and nutrition security and sustainable and inclusive development. With a triple focus on the most vulnerable individuals, organised groups and collective institutions and systems, resilience is an essential means to achieve the multiple challenges of empowerment. At the same time, given the centrality of women in West African societies, empowerment is also an evident way to build the resilience of the region's populations in the face of different shocks and stresses. The first chapter of this paper exposed the linkages between resilience, women's empowerment, and gender equality in a context of change. This link is becoming progressively more apparent and strategic as climate change and diffused insecurity predict an even greater demand for health care across the region in the future. A fairer allocation of care responsibilities between women and men, supported by more effective systems for service delivery that bring together public, private and not-for-profit actors, while keeping resilience and food security objectives in mind, is necessary.

The multidimensional nature of these objectives raises the importance of integrated approaches, and consensus is growing that systems approaches are best-suited for understanding and achieving resilience and sustainable development. The four main dimensions of food security - availability, access, utilisation and stability of supply — also demand interventions well beyond food production to encompass education, health, infrastructure, water and sanitation, trade, agriculture, macroeconomic policies, market frameworks and social protection, to name a few.

\section{NOTES}

1. The 2030 Sustainable Development Agenda builds on the outcomes of the following four global conferences held in 2015: the Third UN World Conference on Disaster Risk Reduction (Sendai, Japan, 14-18 March); the Third International Conference on Financing for Development (Addis Ababa, Ethiopia, 13-16 July 2015); the UN Sustainable Development Summit (New York, United States, 25-27 September); and the Twenty-first Conference of the Parties to the United Nations Framework Convention on Climate Change (Paris, France, 30 November-12 December).The UN Secretary-General urged the international community not to "leave anyone behind" opening the Addis Ababa Conference. For an analysis of the potential for change behind this commitment, see Melamed, 2015. For a critique of its use with reference to the SDGs, see Bigg, 1 March 2016.

2. The SDGs came into effect in January 2016 for implementation and monitoring at the sub-national, national, regional and global levels. Governments are called to align policies, legislation and resources towards their achievement, which take into account national and local specificities, contexts and capacities.

3. i.e. The various types of offices or ministries for women's affairs established by governments following the international statements adopted at all four UN conferences on women (OECD/ DAC, 1998: 39).

4. Borrowing from Leach (2015: 7), pathways indicate "alternative directions of intervention and change. [They refer to] the way that systems or assemblage of social, political, institutional, ecological and technological processes, interacting in dynamic ways in particular environments, may develop over time".

5. This section of the paper draws on the outline paper prepared in June 2015 to frame the analysis and call for contributions from West African actors and their partners. See Gnisci, 2015.

6. Here the West African region includes: Benin, Burkina Faso, Cape Verde, Chad, Côte d'Ivoire, The Gambia, Ghana, Guinea, Guinea-Bissau, Liberia, Mali, Mauritania, Niger, Nigeria, Senegal, Sierra Leone and Togo.

7. All ECOWAS countries appear to be both countries of immigration and emigration, but Côte d'Ivoire and Ghana attract the highest number of immigrants from other ECOWAS countries (ICMPD, IOM, and ECOWAS, 2015: 24).

8. Gender roles describe the behaviours, tasks and responsibilities that a society considers appropriate for women and men, boys and girls; whereas gender relations are the ways in which a society defines the rights, responsibilities and identities of men and women in relation to one another (FAO web resources on gender accessed on 2 March 2016). Both are learned, socially constructed, and influenced by class, age, caste, ethnicity and religion, among other factors (FAO, 2011b; Leach, 2015). 
9. The women in development approach "calls for greater attention to women in development policy and practice, and emphasises the need to integrate them into the development process". The gender in development approach, on the other hand, "focuses on the socially constructed basis of differences between men and women and emphasises the need to challenge existing gender roles and relations" (Reeves and Baden, 2000: 33). Gender mainstreaming is "the process of assessing the implications for women and men of any planned action, including legislation, policies or programmes, in all areas and at all levels. It is a strategy for making women's as well as men's concerns and experiences an integral dimension of the design, implementation, monitoring and evaluation of policies and programmes in all political, economic and societal spheres so that women and men benefit equally and inequality is not perpetuated. The ultimate goal is to achieve gender equality" (United Nations Office of the Special Adviser on Gender Issues, 2002: 1).

\section{REFERENCES}

African Centre for Economic Transformation (2013), "West Africa Trends", ACET Newsletter, Issue 6.

AfDB (2015), Empowering African Women: An Agenda for Action. Africa Gender Equality Index 2015, African Development Bank, Abidjan, http://www.afdb.org/fileadmin/uploads/afdb/ Documents/Publications/African_Gender_Equality_Index_2015-EN.pdf.

AfDB (2014), Gender, Poverty and Environmental Indicators on African Countries, Vol XV, African Development Bank, Tunis.

AfDB, OECD and UNDP (2014), African Economic Outlook 2014: Global Value Chains and Africa's Industrialisation, OECD Publishing, Paris, http://dx.doi.org/10.1787/aeo-2014-en.

AGIR Sahel and West Africa (2013), Regional Road Map, OECD/SWAC, Paris, https://www.oecd. org/swac/publications/AGIR\%20roadmap_EN_FINAL.pdf.

Allen, T. and P. Heinrigs (2016), "Emerging Opportunities in the West African Food Economy", West African Papers, No. 01, OECD Publishing, Paris, http://dx.doi.org/10.1787/5jlvfj4968jb-en.

de Bruijn, M.E. and J.W.M. van Dijk (2006), Climate change and climate variability in West Africa, African Studies Centre, Leiden.

Bigg, T. (1 March 2016), "Does 'leave no-one behind' risk too narrow a focus?", IIED Blog, http://www.iied.org/does-leave-no-one-behind-risk-too-narrow-focus.

Chauveau, J-P and P. Richards (2008), "West African insurgencies in agrarian perspective: Côte d'Ivoire and Sierra Leone compared", Journal of Agrarian Change, No. 8 (4), pp. 515-552, http://dx.doi.org/10.1111/j.1471-0366.2008.00179.x.

CBD Secretariat (2004), Gender and biodiversity, Convention on Biological Diversity Secretariat, Montreal.

Dakora, E. A.N. (2012), "Exploring the fourth wave of supermarket evolution: concepts of value and complexity in Africa", International Journal of Managing Value and Supply Chains, Vol. 3, No. 3, September, pp. 25-37.

Djoudi, H. and M. Brockhaus (2011), "Is adaptation to climate change gender neutral? Lessons from communities dependent on livestock and forests in northern Mali", International Forestry Review, vol 13/2, pp. 123-135.

Doucoure, K. (21 January 2015), "Africa is progressing slowly but surely on rural women's empowerment", interview published in Afronline, http://www.afronline. org/?p=37908\#more-37908

Duflo, E. (2011), Women's empowerment and economic development", Working Paper 17702 , National Bureau of Economic Research, Cambridge, MA.

Duflo, E. and C. Udry (2004), "Household resource allocation in Côte d'Ivoire: Social norms, separate accounts and consumption choices", National Bureau of Economic Research, Working Paper No. 10498, Cambridge, MA, http://dx.doi.org/10.3386/w10498.

Elwell, N. and Y. Williams (7 March 2016), "If you care about the environment, you should care about gender", World Resources Institute blog, http://www.wri.org/blog/2016/03/if-youcare-about-environment-you-should-care-about-gender?utm_campaign=socialmedia\&utm_ source=facebook.com\&utm_medium=wri-page

ECOWAS and SWAC/OECD (2008), Livestock and regional market in the Sahel and West Africa. Potentials and challenges, SWAC/OECD, Paris,www.oecd.org/swac/publications/41848366.pdf

ECOWAS and SWAC/OECD (2008), "Climate and Climate Change", Atlas on regional integration in West Africa, SWAC/OECD , Paris, January.

ECOWAS and SWAC/OECD (2006), "Cotton", Atlas of Regional Integration in West Africa, SWAC/ OECD, Paris, August.

Esquivel, V. (2016), "Power and the Sustainable Development Goals: A feminist analysis", Gender \& Development, Vol. 24, No. 1, Oxfam, Routledge, pp. 9-23, http://dx.doi.org/10.1080/13552074. 2016.1147872 
Evaluation Cooperation Group (2012), Gender equality and development evaluation Units: Lessons from development support of selected multilateral and bilateral agencies, ECG Paper No. 5, IFAD, Rome.

Expert Group Meeting (2016), Report of the Expert Group Meeting on the CSW 60 Priority Theme: Women's Empowerment and the link to Sustainable Development, UN Women, New York.

FAO (2015), Regional overview of food insecurity: African food insecurity prospects brighter than ever, Food and Agriculture Organization, Accra.

FAO (2011a), The role of women in agriculture, Food and Agriculture Organization, Rome.

FAO (2011b), Gender and climate change research in agriculture and food security for rural development: Training Guide, Food and Agriculture Organization, Rome.

FAO and IFAD (2013), Rebuilding West Africa's food potential: policies and market incentives for smallholders-inclusive food value chains, Food and Agriculture Organization, Rome.

FAO, IFAD and WFP (2015), The State of Food Insecurity in the World 2015, Meeting the 2015 international hunger targets: taking stock of uneven progress, FAO, Rome.

Ferrant,G. and A. Kolev (2016), "Does gender discrimination in social institutions matter for longterm growth?: Cross-country evidence”, OECD Development Centre Working Papers, No. 330, OECD Publishing, Paris, http://dx.doi.org/10.1787/5jm2hz8dgls6-en.

Forsythe, L. et al.(2015), Achieving Dryland Women's Empowerment: Environmental Resilience and Social Transformation Imperatives, Natural Resources Institute, University of Greenwich, Chatham, UK.

Fraser, J., V. Frausin and A. Jarvis (2015), "An intergenerational transmission of sustainability? Ancestral habitus and food production in a traditional agro-system of the Upper Guinea Forest, West Africa", Global Environmental Change, Elsevier, Vol. 31, March, pp. 226-238, http://dx.doi. org/10.1016/j.gloenvcha.2015.01.013.

Gafsi, M. et al. (2007), Exploitations agricoles familiales en Afrique de l'Ouest et du Centre, CTA, éditions Quae, Versailles.

Gnisci, D. (2015), “Women's agency for food security and resilience: Women's empowerment and gender equality in West Africa", Paper Outline, OECD/SWAC, Paris, June.

Gnisci, D. (23 June 2015), "Call for contributions: What is the current state of women's empowerment in West Africa", Sahel and West Africa Club Blog, https://oecd-developmentmatters.org/2015/06/23/womens-empowerment/.

von Grebmer, K. et al. (2014), 2014 Global Hunger Index: The Challenge of Hidden Hunger, Bonn, Washington, D.C., and Dublin: Welthungerhilfe, International Food Policy Research Institute, and Concern Worldwide. http://dx.doi.org/10.2499/9780896299580.

Hollinger, F. and J.M. Staatz (eds.) (2015), Agricultural Growth in West Africa: Market and Policy Drivers, AfDB and FAO, Rome.

Ickowicz, A. et al. (2012), "Crop-livestock production systems in the Sahel - increasing resilience for adaptation to climate change and preserving food security", in Building resilience for adaptation to climate change in the agriculture sector, FAO and OECD, Rome, pp. 261-294.

ICMPD, IOM and ECOWAS (2015), A survey on Migration Policies in West Africa, International Centre for Migration Policy Development and the International Organization for Migration, Dakar.

IFAD (2015), Gender and rural development brief, International Fund for Agricultural Development, Rome, May.

IFAD (2010), Gender and desertification: Expanding roles for women to restore dryland areas, International Fund for Agricultural Development, Rome.

Inter-Réseaux (2013), "La promotion de la résilience au Sahel: changement d'approche ou nouvelle mode ?", Bulletin de synthèse de souveraineté alimentaire, No. 8, Inter-réseaux, Paris.

Jalloh, A. et al. (eds.) (2013), West African agriculture and climate change: A comprehensive analysis, IFPRI Research Monograph, International Food Policy Research Institute, Washington D.C., http://dx.doi.org/10.2499/9780896292048.

Kabeer, N. (2012), "Women's economic empowerment and inclusive growth: Labour markets and enterprise development", SIG Working Papers, No. 2012/1, IDRC and DFID, London.

Kaminsky, J. (2008), "Cotton-cereal systems in West and Central Africa: Opportunities and constraints for revenue-raising diversification and marketing strategies", FAO Working Paper under the EU AAACP Project, Food and Agriculture Organization.

Kumar, N. and A. Quisumbing (2014), Gender, shocks and resilience, 2020 Conference Brief 11, May 17-19, Addis Ababa, Ethiopia, International Food Policy Research Institute, Washington, D.C., http://ebrary.ifpri.org/cdm/ref/collection/p15738coll2/id/128143.

Kuwonu, K. (2015), "Le cadre légal et politique de l'autonomisation des femmes en Afrique de l'Ouest", presentation at the Sahel and West Africa Forum, Sahel and West Africa Week, 26-27 October, Milan, Italy, http://www.oecd.org/swac-expo-milano/ presentationsanddocuments/session-4-kuwonu-wildaf.pdf.

Leach, M. (ed.) (2015), Gender equality and sustainable development, Routledge, London. 
Lele, U. (1986), "Women and structural transformation", Economic Development and Cultural Change, Vol. 34, pp. 195-221.

Meinzen-Dick, R., C. Kovarik and A. Quisumbing (2014), "Gender and Sustainability", Annual Review of Environment and Resources, Vol. 39, pp. 29-55, http://dx.doi.org/10.1146/annurevenviron-101813-013240.

Melamed, C. (2015), Leave no one behind. How the SDGs can bring real change, Development Progress, March, Overseas Development Institute, London.

Moriconi-Ebrard, F., D. Harre and P. Heinrigs (2016), Urbanisation Dynamics in West Africa 1950 2010: Africapolis I, 2015 Update, West African Studies, OECD Publishing, Paris, http://dx.doi. org/10.1787/9789264252233-en.

OECD (2015), States of Fragility 2015: Meeting Post-2015 Ambitions, OECD Publishing, Paris, http://dx.doi.org/10.1787/9789264227699-en.

OECD (2012), Closing the Gender Gap: Act Now, OECD Publishing, Paris, http://dx.doi. org/10.1787/9789264179370-en.

OECD/DAC (2014), Guidelines for resilience system analysis, OECD, Paris.

OECD/DAC (1998), DAC source book on concepts and approaches linked to gender equality, OECD, Paris.

OECD/SWAC, (2013), Settlement, Market and Food Security, West African Studies, OECD Publishing, Paris, http://dx.doi.org/10.1787/9789264187443-en.

OECD/SWAC (2009), "Climate Change in West Africa", SWAC Briefing Note, No.3, OECD/SWAC, Paris.

OECD/SWAC (2006), Cotton in West Africa: The Economic and Social Stakes, The Development Dimension, OECD Publishing, Paris, http://dx.doi.org/10.1787/9789264025066-en.

Otoo, M. et al. (2009), Women Entrepreneurship in West Africa: The Cowpea Street Food Sector in Niger and Ghana, Institut National de Recherche Agronomique du Niger, Niamey.

Oxaal, Z. and S. Baden (1997), "Gender and empowerment: Definitions, approaches and implications for policy”, Report No. 40, BRIDGE Development - Gender, Institute of Development Studies, Brighton.

OECD/SWAC (2002), L'économie locale d’Odienné (Denguélé) - Volume 1, Écoloc, Gérer l'économie localement en Afrique : Évaluation et prospective, OECD Publishing, Paris, http://dx.doi. org/10.1787/9789264062900-fr.

Quisumbing, R. and R. Meinzen-Dick (2001), Empowering women to achieve food security. Focus 6, International Food Policy Research Institute, Washington D.C.

Reeves, H. and S. Baden (2000), "Gender and development: concepts and definitions", Report No. 55, BRIDGE Development - Gender, Institute of Development Studies, Brighton.

Sandars, S. (8 October 2015), "Women's empowerment in West Africa: Increasing access to reproductive health services and rights is crucial", Sahel and West Africa Club Blog, https:// oecd-development-matters.org/2015/10/08/womens-empowerment-west-africa-marie-stopes/.

Sen, A. (2001), "The Many Faces of Gender Inequality", Frontline, Vol. 18, Issue 22, 27 October-9 November.

Sen, A. (1999), Development as Freedom, Oxford University Press, Oxford.

Sen, A. (1995), "Gender inequality and theories of justice", in Women, Culture and Development: A Study of Human Capabilities, Clarendon Press, Oxford, pp. 259-273, http://dx.doi.org/10.1093/0 198289642.003.0011.

SWAC/OECD (2016), Resilience and food security in West Africa. Innovative policy approaches in a context of change, Summary Record of the Sahel and West Africa Forum, Sahel and West Africa Week, 26-27 October 2015, Milan, Italy, SWAC/OECD, Paris.

Tacoli, C., et al. (2014), "Building resilience to environmental change by transforming gender relations”, Briefing, International Institute for Environment and Development, London, May.

Teigner, M. and D. Cuberes (2015), "Aggregate costs of gender gaps in the labor market: A quantitative estimate", UB Economics Working Papers, 2014/308, Universitat de Barcelona, Barcelona.

United Nations Framework Convention on Climate Change (12 December 2015), Adoption of the Paris Agreement, FCCC/CP/2015/L.9.

United Nations General Assembly (25 September 2015), Resolution 70/01, Transforming our world: the 2030 Agenda for Sustainable Development, A/70/L.1.

United Nations Office of the Special Adviser on Gender Issues (2002), Gender mainstreaming: An overview, United Nations, New York.

UNDESA (2010), Achieving gender equality, women's empowerment and strengthening development cooperation, United Nations, New York.

UNDP (2014), Human Development Report 2014: Sustaining human progress, reducing vulnerability and building resilience, United Nations Development Programme, New York. 
UNDP (2013), Powerful synergies: Gender equality, economic development and environmental sustainability, United Nations Development Programme, New York.

UNECA (2014), MDG2014 Report. Assessing progress in Africa towards the Millennium Development Goals, United Nations Economic Commission for Africa, African Union, African Development Bank and United Nations Development Programme, Addis Ababa.

UNECA - African Centre for Gender (2014), "Twenty-year review of the implementation of the Beijing Declaration and Platform for Action", Africa Regional Review, Summary Report 1995-2014, United Nations Economic and Security Council, Addis Ababa.

UNEP (2005), Women and the environment, United Nations Environment Programme, Nairobi.

UNEP (n.d.), Women and the environment, United Nations Environment Programme, Nairobi.

UNFPA (2015a), State of World Population 2015, United Nations Population Fund, New York.

UNFPA (2015b), State of world population. Shelter from the storm, United Nations Population Fund, New York.

UN Women (2014), The World Survey on the role of women in development 2014: Gender equality and sustainable development, UN Women, New York.

UN Women - West and Central Africa Regional Office (2014), The gender agenda in West and Central Africa, UN Women - West and Central Africa Regional Office, Dakar.

Weatherspoon D.D. and T. Reardon (2003), "The rise of supermarkets in Africa: Implications for agrifood systems and the rural poor", Development Policy Review, Vol. 21, No. 3, May, pp. 1-17, http://dx.doi.org/10.1111/1467-7679.00214.

World Bank (2014), Levelling the field: improving opportunities for women farmers in Africa, the World Bank, Washington, D.C.

World Bank (2012), World Development Report. Gender equality and development, the World Bank, Washington, D.C.

\section{Websites}

Africa Gender Equality Index:

www.afdb.org/en/topics-and-sectors/topics/quality-assurance-results/gender-equality-index

Africa Gender Innovation Lab (GIL):

www.worldbank.org/en/programs/africa-gender-innovation-lab

Africa Union - Agenda 2063:

http://agenda2063.au.int/en/vision

EmpowerWomen:

www.empowerwomen.org/en

FAO document repository:

www.fao.org/documents/en

FAO - web resources on gender:

www.fao.org/gender/gender-home/en/?no_cache $=1$

IFAD - web resources on gender:

www.ifad.org/gender/resources/publications.htm

The Future of Food:

www.futureoffood.ox.ac.uk/what-food-system

Gender Inequality Index:

http://hdr.undp.org/en/content/gender-inequality-index-gii

The Hub Rural:

www.hubrural.org

Human Development Index:

http://hdr.undp.org/en/content/human-development-index-hdi

OECD Gender Data Portal:

www.oecd.org/gender/data

SIGI - Social Institutions \& Gender Index:

www.genderindex.org

Sustainable Development Knowledge Platform:

https://sustainabledevelopment.un.org 
Third International Conference on Financing for Development:

www.un.org/esa/ffd/ffd3

UN Women - Beijing and its follow up:

www.un.org/womenwatch/daw/beijing/platform

United Nations Department of Economic and Social Affairs (UNDESA) - Population Division:

http://esa.un.org/unpd/wpp

UNDP - Human Development Data:

http://hdr.undp.org/en/data

IPU - Inter-Parliamentary Union - Women in parliament:

www.ipu.org/wmn-e/classif.htm

World Farmers' Organisation:

www.wfo-oma.com

World Health Organisation - Information on Ebola:

www.who.int/csr/disease/ebola/note-ebola-food-safety/en 